\title{
PENGARUH PENERAPAN METODE THINK PAIR SHARE TERHADAP KETERAMPILAN BERBICARA SISWA TUNAGRAHITA SMPLB PUTRA MANDIRI SURABAYA
}

\author{
Nawal Abdina Sandy \\ SMALB-B Karya Mulia \\ nawalabdina08@gmail.com
}

\begin{abstract}
ABSTRAK
Penelitian ini akan membahas tentang Pengaruh metode Think Pair Share terhadap Keterampilan Berbicara Siswa Tunagrahita SMPLB Putra Mandiri Surabaya. Permasalahan yang ada dalam penelitian ini adalah kurangnya keterampilan berbicara siswa tunagrahita yang menjadi subjek penelitian. Kurangnya keterampilan berbicara siswa tunagrahita ini disebabkan oleh beberapa factor yang juga akan dibahas dalam penelitian ini. Penelitian ini merupakan jenis penelitian kuantitatif dengan desain One-Group Pre-Test dan Post-test, yaitu pemberian tes sebelum pemberian perlakuan dan tes sesudah pemberian perlakuan. Yang menjadi subjek penelitian adalah siswa yang mengalami ketunaan jenis tunagrahita, yaitu kurangnya kemampuan untuk berkonsentrasi dan lambat belajar di SMPLB Putra Mandiri Surabaya. Teknik analisis data yang digunakan dalam penelitian ini adalah dengan menggunakan rumus persentase dan T-Test. Hasil penelitian menyebutkan bahwa penerapan metode Think Pair Share memberi dampak positif terhadap keterampilan berbicara siswa tunagrahita SMPLB Putra Mandiri Surabaya.
\end{abstract}

Kata kunci: Tunagrahita, Think Pair Share, Keterampilan Berbicara.

\begin{abstract}
This study will discuss the effect of the Think Pair Share method on Speaking Skills in Mentally Disabled Students at Putra Mandiri Surabaya. The problem in this study is the lack of speaking skills of mentally retarded students who are the subject of research. The lack of speaking skills of mentally retarded students is caused by several factors which will also be discussed in this study. This research is a kind of quantitative research with the design of One-Group Pre-Test and Post-test, which is giving a test before giving treatment and tests after administration of treatment. The subjects of the study were students who experienced the disability of the type of mental retardation, namely the lack of ability to concentrate and slow learning at Putra Mandiri Surabaya SMPLB. The data analysis technique used in this study is to use the percentage formula and T-Test. The results of the study stated that the application of the Think Pair Share method had a positive impact on the speaking skills of mentally retarded students at Putra Mandiri Surabaya Junior High School.
\end{abstract}

Keywords: Mental Retardation, Think Pair Share, Speaking Skills. 


\section{PENDAHULUAN}

Berbicara merupakan aspek penting yang harus dikuasai oleh setiap individu. Berbicara juga merupakan salah satu aspek dar keterampilan berbahasa. Empat komponen tersebut adalah menyimak,berbicara, membaca dan menulis (Tarigan, 2008:1). Dengan berbicara setiap individu dapat berkomunikasi dan melakukan interaksi dengan orang lain. Dengan berbicara juga, setiap insane manusia dapat mengutarakan perasaan, menyampaikan suatu maksud dan tujuan, serta dapat memberikan energi positif untuk orang lain melalui sugesti-sugesti dan motivasi yang dapat membangun kesejahteraan hidup. Untuk dapat membalas pesan, menyampaikan idea tau gagasan, menanggapi persoalan dan polemik yang terjadi, manusia mengandalkan kemampuan berkomunikasi lewat berbicara. Tarigan (2008:16) berpendapat bahwa berbicara merupakan kemanpuan mengucapkan bunyi-bunyi artikulasi atau kata-kata untuk mengekspresikan, menyatakan atau menyampaikan pikiran, gagasan dan perasaan.

Berbicara memang alat yang tepat untuk manusia mengutarakan maksud dan tujuan sesuatu. Berbicara juga dapat melatih seseorang untuk berani berinteraksi dengan orang lain, terutama untuk anak-anak yang masih belajar bicara. Namun, tidak menutup kemungkinan berbicara juga dapat mengalami gangguan. Beberapa faktor dapat mempengaruhi kemampuan berbicara seseorang, diantaranya : Faktor keturunan, gangguan berbicara yang disebabkan oleh penyakit, gangguan pendengaran, faktor kejiwaan seperti penyakit autisme, faktor orang tua dan lingkungan, anak yang mengalami gangguan pada otot bicara.

Anak yang memiliki keterbatasan kognitif, dan anak yang mengalami gangguan pervasive (gangguan pusat syaraf). Faktor-faktor tersebut dapat menghambat keterampilan berbicara seseorang khususnya anak-anak. Anak-anak memang rentan mengalami gangguan-gangguan yang dapat menghambat perkembangan tubuh mereka. Bukan hanya perkembangan tubuh, faktor-faktor tersebut dapat menghambat kemampuan berbicara mereka untuk berkomunikasi dengan orang lain.

Dalam dunia pendidikan ditemukan anak-anak yang memiliki kecerdasan diatas rata-rata anak pada umunya dan cepat dalam belajar. Disamping itu dalam dunia pendidikan juga ditemukan anak-anak yang memiliki kecerdasan dibawah rata-rata pada umumnya. Anak-anak yang memiliki kecerdasan dibawah rata-rata pada 
umumnya, disebut anak terbelakang mental (mentally retarded), istilah resmi yang digunakan di Indonesia adalah anak tunagrahita (PP No 72 tahun 1991).

Setiap individu memiliki kemampuan dan potensi yang berbeda-beda. Kemampuan berbicara seseorang dapat kita nilai sejak seseorang tersebut masih kecil. Perbedaan perkembangan tersebut adalah ada yang cepat tanggap dan ada juga yang mengalami keterlambatan. Menurut Syaodih (2003:14), pada masa awal sekolah dasar (usia 6 tahun) anak menguasai sekitar 2500 kata, usia 8 tahun 20000 kata dan pada masa akhir (usia 11-12 tahun) telah menguasai sekitar 50000 kata. Berbeda dengan anak yang mengalami ketunaan, salah satunya tuna grahita.Untuk anak yang memiliki kelainan seperti tunagrahita, perkembangan kemampuan berbicara mengalami keterlambatan dibandingkan dengan anak normal pada umumnya.Anak tunagrahita lebih rentan mengalami gangguan bahasa sehingga kemampuan berbicaranya mengalami keterlambatan, tak jarang juga keterampilan berbicara anak yang memiliki ketunaan jenis tunagrahita ini mengalami gangguan dalam pola berkomunikasi dengan orang lain. Hasil penelitian dari Robert Ingall (Rochyadi, 2005), menunjukkan bahwa kebanyakan anak tunagrahita tidak dapat memperoleh keterampilan bahasa yang sempurna. Kecepatan anak tunagrahita dalam memperoleh bahasa jauh lebih lambat dari pada anak normal. Anak yang memiliki ketunaan jenis tunagrahita mengalami kesulitan tertentu dalam menguasai gramatikal. Anak tunagrahita tidak dapat menggunakan kalimat majemuk, ia akan banyak menggunakan kalimat tunggal. Kemampuan pemahaman konsep belajar anak tungrahita berbeda dengan anak normal pada pada umumnya. Anak tunagrahita mengalami kesulitan ketia ia dihadapkan dengan pemahaman materi yang rumit. Pembelajran untuk anak tunagrahita pun berbeda dengan anak normal pada umumnya.

Sunardi (2006) menjelaskan bahwa anak tunagrahita disamping dalam komunikasi sehari-hari cenderung menggunakan kalimat tunggal, pada umumnya mereka juga mengalami gangguan dalam artikulasi.Kualitas suara dam riteme, serta mengalami kelambatan dalam perkembangan bicara.Dapat disimpulkan bahwa halhal tersebut yang menjadi faktor terhambatnya keterampilan berbicara pada siswa tunagrahita. 
Sama halnya dengan anak normal biasanya, anak yang mengalami ketunaan atau kelainan seperti tunagrahita juga layak mendapatkan pendidikan yang layak. Hanya saja materi pelajaran dan pembelajaran didalam kelas memang berbeda. Bedanya adalah pembelajaran yang diberikan untuk anak yang mengalami ketunaan adalah pembelajaran yang lebih sederhana dan lebih nyata, maksudnya adalah media yang digunakan dibuat lebih menarik dan tidak telalu susah untuk digunakan dalam prose belajar didalam kelas. Sekolah untuk anak yang mengalami ketunaan juga dihkhususkan. Anak yang memiliki ketunaan dikhususkan dengan sekolah yang berisi siswa yang memiliki ketunaan pula, sekolah tersebut adalah sekolah luar biasa.

Pendidikan luar biasa adalah pendidikan yang itu ditujukan kepada anak-anak yang berkebutuhan khusus. Apa itu Anak Berkebutuhan Khusus? Anak Berkebutuhan Khusus menurut Heward adalah anak dengan karakteristik khusus yang berbeda dengan anak pada umumnya. ABK selalu menunjukkan pada ketidakmampuan mental, emosi, atau fisik. Yang termasuk kedalam ABK antara lain: tunanetra (buta),tunarungu (tuli), tunagrahita (autis), tunadaksa (penyandang cacat fisik), tunalaras (gangguan emosi. Karena karakteristik dan gangguan yang dimiliki, ABK perlu memperoleh pendidikan khusus untuk memenuhi potensi mereka.

Tunagrahita adalah keadaaan keterbelakangan mental, keadaan ini dikenal juga gangguan mental (mental retardation). Anak tunagrahita memiliki IQ di bawah ratarata anak normal pada umumnya, sehingga menyebabkan fungsi kecerdasan dan intelektual mereka terganggu, yang menyebabkan permasalahan-permasalahan lainnya muncul pada masa perkembangannya. Hal tersebut sejalan dengan AAMD yang dikutip Grossman (Krik\& Gallagher, 1986:116) dan diterjemahkan oleh Astati dan Lismulyati bahwa tunagrahita mengacu pada fungsi intelek umum yang nyata berada di bawah rata-rata bersamaan dengan kekurangan dalam adaptasi tingkah laku dan berlangsung dalam masa perkembangan. Tunagrahita dibagi menjadi 3 jenis yaitu, tunagrahita ringan, tunagrahita sedang dan tunagrahita berat.

Anak tunagrahita ringan adalah mereka yang kecerdasan dan adaptasi sosialnya terlambat, namun mereka mempunyai kemampuan untuk berkembang dalam bidang akademik, Penyesuaian sosial dan kemampuan bekerja (Amin (1995:22). Kondisi fisik anak tunagrahita ringan pada umumnya tidak berbeda dengan anak normal yang lain, dan mempunyai tingkat IQ yang berkisar antara 50-70. Meskipun mengalami 
hambatan pada kecerdasan dan adaptasi sosial siswa tunagrahita masih mempunyai kemampuan di bidang akademik penyesuaian sosial dan kemampuan untuk bekerja. Siswa tunagrahita masih bisa belajar membaca, menulis dan berhitung, Selain itu siswa tunagrahita juga bisa menyelesaikan pendidikan setingkat kelas empat sekolah dasar umum. Seringkali anak tuna grahita ringan tidak dapat diidentifikasi hingga memasuki usia sekolah, ketika anak tersebut mengalami kesulitan dalam mengikuti pelajaran. Sekitar 75\% dari anak tunagrahita yang termasuk dalam kelompok tuna grahitaringan adalah anak yang memiliki gangguan ketunaan mengalami keterlambatan perkembangan.Namun, hal tersebut dapat kita tingkatkan melalui pembelajaran yang menyenangkan.Sehingga anak tunagrahita memiliki semangat untuk terus belajar dan terus berkembang. Salah satu cara agar pembelajaran yang kita berikan terasa menyenangkan adalah dengan memadukan metode belajar yang menyenangkan.

Strategi pembelajaran yang dapat digunakan pada pembelajaran anak tunagrahita adalah strategi pembelajaran yang diindividualisasikan dimana mereka belajar bersama-sama dalam satu kelas tetapi kedalaman dan keluasan materi, pendekatan/metode maupun teknik berbeda-beda di sesuaikan dengan kemampuan dan kebutuhan setiap peserta didik. Namun demikian dapat pula menggunakan strategi lainnya seperti strategi kooperatif, dan strategi modifikasi tingkah laku. Metode mengajar hendaknya harus dipilih agar anak belajar dengan melakukan praktek rangsangan yang di peroleh melalui motorik yang akan cepat diproses dalam pusat berpikir dan tidak mudah di lupakan. Strategi belajar kooperatif tipe think pair share misalnya. Dengan dibantu media cerita bergambar, metode ini diharap mampu membantu meningkatkan keterampilan berbicara siswa tunagrahita.Alat/media yang di gunakan dalam pembelajaran anak tunagrahita harus memperhatikan beberapa kriteria, seperti : anak memiliki tanggapan tentang yang di pelajarinya, tidak mudah rusak, tidak berbahaya, tidak abstrak, dapat di gunakan anak, dan mudah di peroleh. Media yang digunakan dalam penelitian ini adalah media gambar. Siswa akan diminta untuk berpikir isi dari media cerita yang sudah diberikan. Media cerita yang digunakan juga merupakan media cerita bergambar sederhana. Media cerita bergambar sederhana ini akan memudahkan siswa tunagrahita untuk berpikir dan mengekspresikan ide kreatifnya. Ketika siswa tunagrahita mampu mengekspresikan 
isi dari cerita bergambar tersebut, siswa akan mampu mencurahkan ide-ide kreatifnya melalui tulisan. Tulisan yang berisi ide kreatif siswa tuna grahita ini akan menjadi petokan pengingat siswa tunagrahita untuk nantinya dihapalkan dan diceritakan kepada teman-teman sekelasnya. Metode think pair share ini akan dianggap berpengaruh jika siswa tunagrahita berkembang dalam segi keterampilan berbicaranya. Aspek yang menjadi indikator berkembangnya keterampilan berbicara dalam penelitian ini adalah kosakata yang dipakai siswa lebih banyak dan beragam, siswa lebih cakap menceritakan hasil berpikirnya terkait media cerita bergambar kepada teman-teman satu kelas, dan siswa lebih berani untuk mengungkpakan semua ide kreatifnya di depan teman-teman satu kelas mengenai cerita yang sudah buat.

\section{METODE PENELITIAN}

Jenis penelitian ini adalah penelitian kuantitatif eksperimen. Penelitian ini menjelaskan pengaruh dari penerapan metode belajar Think Pair Share terhadap keterampilan berbicara siswa yang mengalami ketunaan jenis tunagrahita dari SMPLB Putra Mandiri Surabaya. Penelitian ini juga menggunakan angka sebagai penjelas dari hasil penelitian. Angka-angka tersebut dapat diketahui dari hasil pemberian pre-test dan post-test pada tahap sebelum pemberian perlakuan dan sesudah pemberian perlakuan. Kemudian, angka-angka tersebut diolah menjadi data nilai untuk menjelaskan besar kecilnya pengaruh dari pemberian perlakuan.

Teknik pengumpulan data dalam penelitian ini berupa teknik tes dan non tes, berikut adalah tahapan-tahapan analisis data:

1. Teknik Tes

Teknik tes yang diberikan oleh peneliti terdiri dari 2 tahap, yaitu Pre-test dan Post-test. Pre-test diberikan kepada masing-masing siswa dengan tema yang seragam. Tema yang dipakai dalam pre-test ini adalah kebun binatang. Siswa secara individu diminta untuk menbuat deskripsi tentang kebun binatang. Tema yang dipakai kebun binatang karena tema tersebut dinilai sudah familiar di kalangan anak-anak. Sama halnya dengan Pre-test, pemberian Post-test juga dengan tema yang sama, yaitu kebun binatang. Post-test diberikan setelah tahap pemberian terlakuan berupa metode pembelajaran. Post-test juga berfungsi untuk alat pembanding antara nilai sebelum dan sesudah diberi perlakuan. 


\section{Teknik Non-tes}

Teknik Non-tes yang ada dalam penelitian ini adalah observasi dan wawancara guru dalam kelas. Observasi yang dilakukan ini bertujuan agar peneliti mengetahui kebiasaan siswa dalam kelas. Wawancara dengan guru juga bertujuan untuk membantu dan memperluas informasi yang diperoleh peneliti untuk melakukan penelitian.

Subjek penelitian ini adalah siswa tunagrahita SMPLB Putra Mandiri Surabaya. Subjek penelitian berasal dari SMPLB Putra Mandiri Surabaya, peneliti juga harus observasi untuk mengetahui kebiasaan-kebiasaan subjek, kemampuan dasar berbicara para subjek. Peneliti juga memerlukan literatur yang berhubungan dengan anak-anak tunagrahita, metode belajar, model belajar, strategi belajar dan lain sebagainya. Teknik pengumpulan data dalam penelitian ini adalah tes dan nontes. Peneliti memberikan pre-test untuk mengetahui kemampuan dasar subjek penelitian sebelum diberi perlakuan. Setelah pre-test selesai, peneliti memberikan perlakuan berupa pemberian metode belajar Think Pair Share. Setelah tahap pemberian perlakuan, peneliti memberikan post-test untuk dibandingkan hasilnya dengan nilai pre-test. Hasil perbandingan nilai pre-test dan post-test tersebut menjadi acuan seberapa besar pengaruh dari pemberian perlakuan oleh peneliti.

\section{PEMBAHASAN}

Penelitian ini diambil di SMPLB Putra Mandiri Surabaya. Yang menjadi subjek dalam penelitian ini adalah siswa-siswa yang mengalami ketunaan jenis tunagrahita. Jumlah subjek dalam penelitian ini berjumlah 4 orang. 2 orang laki-laki dan 2 orang perempuan. Siswa-siswa ini memeiliki jenis ketunaan yang sama, yaitu tunagrahita ringan. Namun, dibalik persamaan tersebut, siswa-siswa ini mememiliki perbadaan karakter dan perbedaan kemampuan. Perbadaan aktif dalam kegiatan belajar mengajar juga tampak dari siswa-siswa yang menjadi subjek penelitian. Para subjek penelitian ini masih bisa diajak berkomunikasi dan dapat membantu penelti untuk menyelesaikan penelitiannya. Siswa dengan baik menerima tugas yang diberikan oleh peneliti. Siswa juga bisa bekerjasama dengan siswa lain yang juga menjadi subjek penelitian. 
Observasi adalah hal yang pertama dilakukan oleh peneliti. Peneliti mendapatkan data awal berupa kebiasaan siswa di kelas, kemampuan dasar, dan keaktifan siswa dalam kegiatan belajar. Selain observasi kelas, peneliti juga mengobservasi siswa yang menjadi subjek dengan cara meminta subjek untuk memperkenalkan diri dari hal yang paling sederhana, mulai dari nama, nama panggilan dan seterusnya terkait dengan diri subjek. Kegiatan observasi ini juga dapat menunjang peneliti untuk melakukan penelitian.

Dengan data-data yang diambil dalam tahap observasi, peneliti dapat terbantu dalam mengolah data. Observasi satu hari, peneliti dapat menemukan kebiasaankebiasaan siswa di kelas. Peneliti juga dapat menilai siswa dengan masing-masing karakternya. Dapat ditemukan 3 siswa yang menjadi subjek penelitian adalah siswa yang aktif berbicara dalam kelas. 1 siswa yang lain merupakan siswa yang pendiam. Namun, ada juga kelebihan yang dapat ditemukan dari siswa yang tergolong pendiam tersebut. Siswa yang pendiam tersebut memiliki keterampilan menulis yang paling bagus diantara teman yang lain. Setelah tahap observasi peneliti memberikan tes awal yaitu pre-test. Pada tahap pre-test peneliti memugaskan siswa untuk mendeskripsikan tema yang sudah diberikan secara seragam. Tema yang diberikan peneliti adalah kebun binatang. Siswa diminta untuk berpikir individu dan mendeskripsikan kebun binatang. Siswa diminta mendeskripsikan kebun binatang lewat tulisan untuk memudahkan siswa berpikir dan mengingat apa yang sudah ia pikirkan. Setelah mendeskripsikan tema yang sudah diberikan, siswa diminta untuk mendeksripsikan hasil pemikirannya lewat berbicara.

Peneliti dapat menilai kemampuan berbicara dasar siswa melalui pre-test ini. Pada saat siswa diminta untuk mendeskripsikan hasil berpikirnya dapat ditemukan perbedaan karakter dan perbedaan hasil. Untuk siswa yang tergolong aktif dalam pembelajaran, terdapat 3 siswa yang baik dalam berbicara. Dalam pre-test ini juga ditemukan 1 siswa perempuan yang sangat kurang dala hal berbicara, ia lebih cenderung diam. Namun, ketika ia diminta menuangkan hasil pemikirannya ke dalam tulisan, hasil tulisannya adalah yang paling banyak. Dari 3 siswa yang tergolong aktif, juga ditemukan 1 siswa laki-laki yang memiliki karakter hyperaktif. Karakter hyperaktif tersebut mempengaruhi keterampilan berbicara siswa tersebut. Hyperaktif membuat siswa tersebut lebih banyak berbicara daripada menulis. Dapat diketahui 
juga untuk 2 siswa lainnya, setelah diamati dari hasil tulisannya, 2 siswa yang terdiri dari siswa laki-laki dan siswa perempuan memiliki keterampilan menulis yang kurang, namun ketika diminta untuk menjelaskan lewat lisan 2 siswa tersebut memilik keterampilan berbicara yang lebih baik dari 2 siswa lainnya. Berikut adalah tabel penilaian Pre-test keterampilan berbicara siswa yang dinilai dari 6 aspek berbicara.

Tabel 1. Penilaian Pre-test

\begin{tabular}{|c|c|c|c|c|c|c|c|c|c|}
\hline No. & Subjek & A & B & C & D & E & F & Skor & Nilai \\
\hline 1. & I & 4 & 3 & 3 & 3 & 2 & 3 & 18 & 60 \\
\hline 2. & A & 3 & 3 & 3 & 3 & 2 & 2 & 16 & 53 \\
\hline 3. & V & 1 & 1 & 1 & 1 & 1 & 1 & 6 & 20 \\
\hline 4. & Y & 4 & 3 & 3 & 3 & 3 & 3 & 19 & 53 \\
\hline & \multicolumn{8}{|c|}{ Jumlah } \\
\hline & \multicolumn{8}{|c|}{ Rata-rata } & $\mathbf{1 8 6}$ \\
\hline
\end{tabular}

Setelah pemberian pre-test kepada para subjek, peneliti melanjutkan tahap penelitian yaitu pemberian perlakuan berupa metode belajar Think Pair Share. Pada saat pemberian perlakuan siswa dapat menerima pembelajaran dengan baik. Siswa diminta untuk membentuk pasangan diskusi. Pada pasangan diskusi tersebut siswa mendiskusikan tema yang sebelumnya telah dipikirkan secara individu. Pada tahap diskus pasangan, pasangan 1 terdiri dari siswa bernama I dan A. Pada pasangan diskusi pertama terlihat 2 siswa ini bekerjasama dengan baik. Mengingat Ibra yang memiliki keterampilan berbicara yang baik diantara teman-temannya, dan A yang merupakan siswa hyperaktif, sehingga memudahkan proses diskusi. Pasangan diskusi pertama saling bahu membahu untuk menemukan informasi sebanyak-banyaknya. Pada pasangan diskusi kedua terdiri dari 2 siswa bernama V dan Y. Y memiliki keterampialn berbicara yang baik sama seperti I. SedangkanV adalah siswa yang pendiam. Namun, dibalik karakter pendiamnya, V memiliki keterampilan menulis yang baik jika dibandingkan teman-temannya. V lebih banyak mengontribusikan hasil pikirannya ke dalam tulisan pasangan diskusi. Tak jarang juga Y meminta V untuk mengeluarkan suaranya untuk berpendapat. Pada tahap diskusi pasangan ini, V mulai mau membuka mulutnya untuk berpendapat. Pada tahap pemberian perlakuan ini, peneliti kembali menilai. 
Setelah tahap pemberian perlakuan terlampaui, penelitian dilanjutkan dengan pemberian post test. Setelah tahap bediskusi pasangan, siswa mengutarakan pendapatnya lewat lisan. Pada tahap ini, keterampilan siswa mulai terlihat. V yang karakternya pendiam mulai menggunakan alat ucapnya untuk berpendapat. Dibantu pasangan diskusinya Y, perlahan-lahan keterampilan berbicara V membaik. Sama seperti halnya dengan pasangan diskusi kedua, pasangan diskusi pertama I dan A juga semakin membaik dalam keterampilan berbicaranya. Berikut ini adalah tabel penilaian post-test keterampilan berbicara siswa tunagrahita SMPLB Putra Mandiri Surabaya.

Tabel 2. Penilaian Post-test

\begin{tabular}{|c|c|c|c|c|c|c|c|c|c|}
\hline No. & Subjek & A & B & C & D & E & F & Skor & Nilai \\
\hline 1. & I & 5 & 5 & 4 & 4 & 4 & 5 & 27 & 90 \\
\hline 2. & A & 5 & 5 & 4 & 4 & 4 & 4 & 26 & 86 \\
\hline 3. & V & 3 & 3 & 3 & 3 & 3 & 3 & 18 & 93 \\
\hline 4. & Y & 5 & 4 & 4 & 5 & 5 & 5 & 28 & 60 \\
\hline & \multicolumn{8}{|c|}{ Jumlah } \\
\hline & \multicolumn{1}{|c|}{ Rata-rata } \\
\hline
\end{tabular}

Keterangan: A : Bunyi

B : Intonasi

C : Ketepatan Kata

D : Urutan Informasi

E : Struktur kalimat

F : cara memulai dan mengakhiri pembicaraan.

Masing-masing subjek penelitian akan dinilai dalam 6 aspek keterampilan berbicara, penilaian tersebut diawali dengan pancapaian skor oleh siswa. Pencapaian skor yang diketahui akan diolah menjadi nilai menggunakan rumus persentase. Setelah diketahui jumlah dari nilai para subjek, nilai tersebut dihitung rata-ratanya menggunakan rumus rata-rata. Pencapaian skor dan nilai siswa diharap mampu melampaui KKM yang ditentukan sekolah. 


\section{PENUTUP}

Penerapan metode Think Pair Share terhadap keterampilan berbicara siswa tunagrahita SMPLB Putra Mandiri Surabaya, berpengaruh positif dan mampu meningkatkan keterampilan berbicara siswa, Terlihat dari hasil pengolahan data nilai dan pencapaian skor oleh siswa yang terbagi dalam 2 tahap yaitu pre-test dan posttest siswa meningkat. Kemampuan untuk berbicara juga meningkat, terlihat dari yang dominan, siswa bernama Vivin yang mempunyai karakter pendiam menjadi berani untuk berpendapat dan mengutarakan ide gagasan yang ia miliki.

\section{DAFTAR PUSTAKA}

Apriyanto, Nunung. 2007. Seluk-Beluk Tunagrahita \& Strategi Pembelajarannya. Jakarta.

Mulyono, Abdurachman. 2012. Anak berkesulitan Belajar, Teori Diagnosis dan Remediasi. Jakarta: Rineka Cipta.

Nasution. 2009. Berbagai Pendekatan Dalam Proses Belajar dan Mengajar. Jakarta: PT Bumi Aksara.

Rusman. 2012. Model-model Pembelajaran, Mengembangkan Profesionalisme Guru. Jakarta: PT. Raja Grafindo.

Sugiyono. 2015. Metode Penelitian Kuantitatif Kualitatif dan R\&D. Bandung : Alfabeta.

Sujinah. 2017. Menjadi Pembicara Terampil. Sleman: CV Budi Utama. 